\title{
Human Anti-Human Antibody
}

National Cancer Institute

\section{Source}

National Cancer Institute. Human Anti-Human Antibody. NCI Thesaurus. Code C103990.

Human antibodies which recognize other human antibodies. These can develop in certain disease states or in response to treatment with therapeutic antibodies which can limit the effectiveness of the treatment. 